\title{
SISTEM INFORMASI PELAYANAN KESEHATAN PASIEN RAWAT INAP PADA RUMAH BERSALIN XAVERIUS TANJUNG KARANG BANDAR LAMPUNG
}

\author{
Reni Agustiani
}

\begin{abstract}
Rumah Bersalin XAVERIUS Tanjung Karang Bandar Lampung merupakan rumah bersalin yang berada dibawah naungan Yayasan Dwi Bhakti Bandar Lampung yang bergerak dalam bidang jasa yang selalu dituntut untuk memberikan pelayanan yang serba cepat, tepat dan akurat. Pemberian pelayanan yang nyaman merupakan suatu tujuan yang ingin dicapai oleh semua unit kerja untuk mennaga citra baik Rumah Bersalin. Sampai saat ini sistem informasi dalam proses pengolahan data masih dilakukan secara semi komputer, sehingga sering terjadi penumpukan data dan pencarian data yang membutuhkan waktu yang cukup lama. Dalam hal ini akan mempengaruhi keterlambatan dalam penyajian informasi karena informasi yang dihasilkan belum dapat secara optimal. Untuk mempermudah kinerja dalam pemrosesan pengolahan data-data pasien khususnya rawat inap pada Rumah Bersalin XAVERIUS, penulis membuat suatu sistem baru dengan menggunakan program Microsoft Visual Basic 6.0 dengan menggunakan database SQL Server dan Crystal Report dalam pembuatan laporan, agar pengolahan data dapat dilakukan secara komputerisasi, sehingga dapat mempercepat proses pengolahan data pasien rawat inap sekaligus meningkatkan efektifitas kerja Rumah Bersalin XAVERIUS Tanjung Karang Bandar Lampung dengan pelayanan pasien yang lebih baik.
\end{abstract}

\section{PENDAHULUAN}

\subsection{Latar Belakang}

Kemajuan teknologi komputer sebagai pendukung pemrosesan data menjadi informasi telah menjadi kebutuhan pokok perusahaan. Teknologi informasi saat ini telah berkembang dengan cepat keberbagai negara maju yang sangat merasakan pentingnya teknologi informasi dalam menunjang pengambilan keputusan yang cepat dan tepat berdasarkan data yang akurat baik dalam bidang perekonomian, politik maupun ilmu pengetahuan. Sistem pengolahan data pasien khusunya pengolahan data rawat inap pada Rumah Bersalin XAVERIUS Tanjung Karang masih dilakukan secara semi komputer. Berdasarkan penelitian yang dilakukan penulis, maka penulis mengambil judul “Sistem Informasi Pelayanan Kesehatan Pasien Rawat Inap pada Rumah Bersalin XAVERIUS Tanjung Karang Bandar Lampung"

\subsection{Rumusan Masalah}

Berdasarkan latar belakang diatas, maka permasalahan yang akan diangkat dalam penelitian mi adalah "Bagaimana merancang dan membuat suatu sistem rawat inap pada Rumah Bersalin XAVERIUS Tanjung Karang Bandar Lampung dengan menggunakan bahasa pemrograman VisualBasic “, sehingga informasi dapat tersaji dengan lebih baik.

\subsection{Batasan Masalah}

Melihat latar belakang masalah diatas, maka penulis tidak mampu membahas seluruh permasalahan yang ada dikarenakan keterbatasan waktu dan tenaga. Untuk membatasi permasalahan yang ada, maka penulis membatasi batasan masalah yaitu mengenal sistem rawat inap pada Rumah Bersalin XAVERIUS Tanjung Karang Bandar Lampung.

\subsection{Tujuan Penelitian}

Tujuan dan penelitian yang ingin dicapai adalah sebagai berikut:

a. Membangun suatu sistem pengolahan data pasien rawat inap dengan program komputer sehingga dapat membantu proses pengolahan data.

b. Meningkatkan efektifitas dan efinsiensi kerja.

\subsection{Manfaat Penelitian}

Manfaat dan hasil penelitian skripsi ini adalah:

a. Memberikan kemudahan bagi pegawai khususnya pada bagian administrasi untuk mengetahui dengan cepat informasi tentang pasien rawat inap.

b. Dapat dijadikan masukkan atau pertimbangan dalam pengembangan dan pemanfaatan teknologi sistem informasi yang ada sebelumnya yang digunakan untuk mendukung efisiensi dalam hal pengolahan data pasien rawat inap.

\subsection{Ruang Lingkup}

Kegiatan penelitian ini dilakukan pada Rumah Bersalin XAVERIUS Tanjung Karang Bandar Lampung. Ruang lingkup dan pembahasan ini mengenai sistern informasi rawat inap pada 
Rumah Bersalin XAVERIUS Tanjung Karang Bandar Lampung, yang nantinya diharapkan dapat memudahkan petugas dalam mengolah data sehingga menghasilkan informasi yang dapat meningkatkan kinerja. Ruang lingkup masalah ini dibatasi dengan kegiatan yang mencakup:

a. Perancangan sistem komputer rawat inap pada Rumah Bensalin XAVERIUS Tanjung Karang Bandar Lampung.

b. Perancangan sistem dengan menggunakan Diagram Context, Data Flow Diagram (DFD), Flowchart dan Desain sistem secara umum.

\section{Metodologi Penelitian Metode Pengumpulan Data}

1. Wawancara (Interview)

Metode pengumpulan data melalui wawancara secara lisan kepada kepala bagian administrasi yang ada, sehingga diperoleh data-data yang akurat.

\section{Pengamatan (Observation)}

Metode pengumpulan data dengan pengamatan langsung pada objek yang dituju sebagai sumber data dan informasi yang tepat.

\section{Tinjauan Pustaka (Library Research)}

Metode pengumpulan dan perolehan bahan secara teoritis sebagai landasan bahan penyusunan laporan ini sehingga diperoleh datadata dan informasi yang akurat.

\subsection{Metode Daur Hidup}

Metode Daur Hidup mi terdiri dan beberapa tahapan proses, yaitu Perencanaan, Tahap Analisis, Tahap Perancangan, Tahap Coding (Penulisan Program), Tahap Pengujian, dan Tahap Pemeliharaan. Adapun penjelasan dari tahapantahapan proses tersebut, yaitu :

1. Tahap Perencanaan

Pada tahap ini sistem mencoba memahami permasalahan-permasalahan yang muncul dan mendefinisikannya secara rinci dan kemudian tujuan pembuatan sistem dan mengidentifikasikan kendala-kendala. Melakukan analisis terhadap sistem pelayanan kesehatan rawat inap.

2. Tahap Analisis

Pada tahap ini dilakukan analisis mengenai software yang akan digunakan pada Sistem Informasi Pelayanan Kesehatan Pasien Rawat Inap pada Rumah Bersalin XAVERIUS Tanjung Karang Bandar Lampung. Disini juga sistem akan dianalisis secara mendalam.

\section{Tahap Perancangan}

Pada tahap ini dilakukan desain terhadap tampilan atau layout program yang akan dibuat dengan mengkombinasikan warna, tata letak, jenis huruf, gambar dan lain sebagainya sehingga bisa menarik perhatian pemakai serta memperindah tampilan program.

\section{Tahap Coding (Penulisan Program)}

Pada tahap ini merealisasikan ide-ide yang akan dibuat sesuai dengan analisa yang dilakukan sebelumnya sesuai dengan perancangan yang diinginkan.

\section{Tahap Pengujian}

Pada tahap ini dilakukan pengujian terhadap rincian logika software. Pengujian dilakukan untuk mengungkapkan dan menghilangkan kesalahan kesalahan yang ada.

\section{Tahap Pemeliharaan}

Pada tahap ini meliputi pemeliharaan sistem yang telah dibuat yang disesuaikan dengan perkembangan software yang ada.

\section{TINJAUAN PUSTAKA \\ 3.1 Konsep Dasar Sistem}

\section{Pengertian Sistem}

Terdapat dua kelompok pendekatan di dalam mendefinisikan sistem, yaitu pendekatan yang menekankan pada prosedurnya dan pendekatan yang menekankan pada komponen atau elemennya. "Suatu sistem adalah suatu jaringan kerja dari prosedur-prosedur yang saling berhubungan, berkumpul bersama-sama untuk melakukan suatu kegiatan atau untuk menyelesaikan suatu sasaran yang tertentu ") ( Jogiyanto : $2001: 1$ )

\subsection{Pengertian Informasi}

Informasi ibarat darah yang mengalir dalam tubuh suatu organisasi, sehingga informasi ini sangat penting di dalam suatu organisasi. Suatu sistem yang kurang mendapatkan informasi akan menjadi luruh, kerdil dan akhirnya berakhir. Robert N Anthony dan John Dearden menyebut dari sistem dalam hubungannya dengan berakhirnya dengan istilah entropy.

\subsubsection{Pengertian Sistem Informasi}

Telah diketahui bahwa informasi merupakan hal yang sangat penting bagi manajemen di dalam pengambilan keputusan. Sistem informasi didefinisikan oleh Robert $\boldsymbol{A}$. Leitch dan K. Roscoe Davis, sebagai berikut, sistem informasi adalah " suatu sistem di dalam suatu organisasi yang mempertemukan kebutuhan organisasi yang mempertemukan kebutuhan 
pengolahan biaya harian, mendukung operasi, bersifat menejerial dan kegiatan strategi dari suatu organisasi dan menyediakan pihak luar tertentu dengan laporan-laporan yang diperlukan " ( Jogiyanto : $2001: 11$ )

\subsubsection{Pengertian Pelayanan}

Pelayanan adalah suatu kegiatan atau urutan kegiatan yang terjadi dalam interaksi langsung antara orang lain atau mesin secara fisik, dan menyediakan kepuasan pelanggan.

\subsubsection{Pengertian Pasien}

Pasien yang umumnya datang untuk mendapatkan pengobatan di dokter. Pasien adalah “ orang yang sakit yang berada dibawah perawatan seorang dokter, penderita penyakit yang berobat ditempat praktek dokter, bidan, rumah sakit, klinik “. ( Kamus Besar Bahasa Indonesia, 2007 : 648 ).

\subsubsection{Pengertian Rumah Bersalin}

Rumah Bersalin adalah suatu tempat pemberian pelayanan kesehatan bagi ibu hamil dan melahirkan yang dilakukan secara medis oleh para dokter atau bidan.

\subsubsection{Pengertian Rawat Inap}

Rawat Inap adalah proses perawatan bagi pasien yang membutuhkan pelayanan kesehatan, menginap dan dirawat.

\section{Bagan Alir Sistem ( Systems Flowchart)}

Bagan Alir Sistem (Systems Flowchart) merupakan bagan yang menunjukkan arus pekerjaan secara keseluruhan dari sistem, ( Jogiyanto : 2001 : 796 ). Bagan Alir Sistem ini menjelaskan urutan-urutan dari prosedur-prosedur yang ada didalam sistem

\subsubsection{Bagan Alir Program ( Program Flowchart )}

Bagan Alir Program (Program Flowchart ) merupakan bagan yang menjelaskan secara rinci langkah-langkah dari proses program. Bagan alir program dibuat secara derivikasi bagan alir sistem., ( Jogiyanto : $2001: 802$ ).

\subsubsection{Pengertian Data Flow Diagram ( DFD )}

Pada tahap analisis, penggunaan notasi sangat membantu sekali di dalam komunikasi dengan pemakai sistem untuk memahami sistem secara logika. Diagram yang menggunakan notasinotasi ini untuk menggambarkan arus dari data sistem sekarang dikenal dengan nama diagram arus data ( Data Flow Diagram ),( Jogiyanto : 2001 : $700)$.

\subsubsection{Pengertian Kamus Data}

Kamus data atau data dictionary atau disebut juga dengan sistem data directory, adalah katalog fakta tentang data dan kebutuhan- kebutuhan informasi dari suatu sistem informasi. ( Jogiyanto : 2001 : 725).

\subsubsection{Relasi Data ( Entity Relation Diagram / $E-R D)$}

Entity Relation Diagram merupakan suatu komponen-komponen himpunan entitas dan himpunan relasi yang masing-masing dilengkapi dengan atribut yang mempresentasikan seluruh fakta dari dunia nyata yang ditinjau. Entity Relation Diagram menggambarkan data dan hubungan antar data secara global dengan menggunakan Entity Relation Diagram.

\section{Microsoft Visual Basic 6.0}

Visual Basic 6.0 pada dasarnya adalah sebuah bahasa pemrograman komputer. Bahasa pemrograman adalah perintah-perintah atau intruksi yang dimengerti oleh komputer untuk melakukan

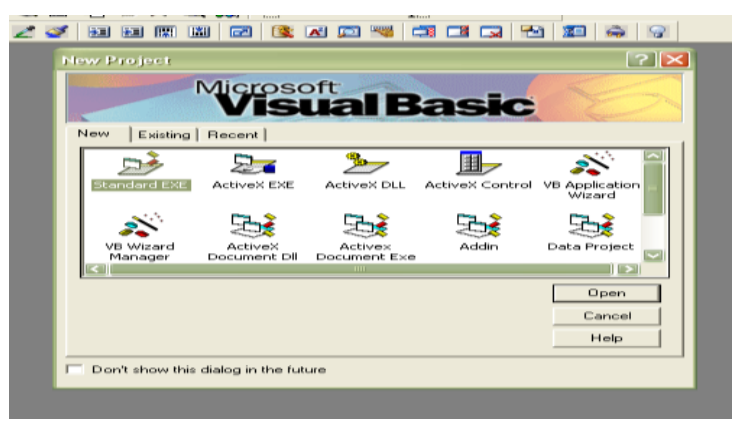

tugas tertentu. ( Adi Kurniadi, 1999:3 )

\section{Antarmuka Dan Lingkungan Kerja Visual Basic 6.0}

Visual Basic merupakan sebuah program aplikasi Windows, maka itu kita harus dapat menjalankan dari Windows, yang harus dilakukan adalah pada menu Start pilihmenu Program > Microsoft Visual Basic 6.0maka akan muncul kotak dialog maka pilihlan jenis aplikasi yang kita inginkan.

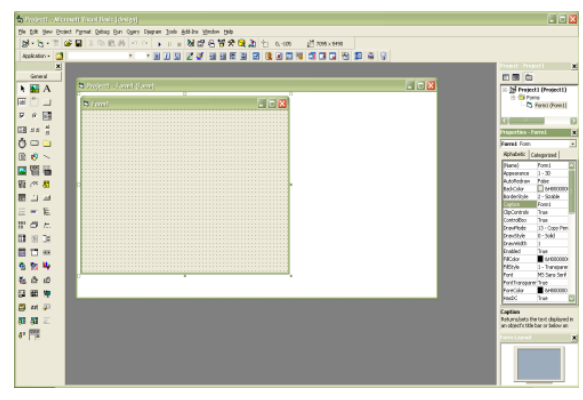

Gambar 2.12 Kotak Dialog New Project 
Kerja Visual Basic

Komponen Visual Basic 6.0

Control Menu

Control Menumerupakan menu yang digunakan terutama untuk memanipulasi jendela Visual Basic 6.0.

\section{Menu}

Menu Visual Basic berisi semua perintah Visual Basic yang dapat dipilih untuk melakukan tugas tertentu. Isi dari menu ini sebagian hampir sama dengan program-program Windows pada umumnya.

\section{Toolbar}

Toolbaradalah tombol-tombol yang mewakili suatu perintah tertentu dari Visual Basic. Setiap tombol tersebut dapat langsung diklik untuk melakukan perintah tertentu. Biasanya tomboltombol tersebut merupakan perintah-perintah yang sering digunakan dan terdapat pada menu Visual Basic.

\section{Bahasa Basis Data Relasional}

Dalam implementasi penyusunan basis data relational pada umumnya digunakan bahasa standar yang dikenal dengan sebutan SQL (Structural Query Language). SQL merupakan bahasa implementasi dari basis data relational hasil penelitian IBM dan digunakan pada hampir semua produk Database Management Sistem (DBMS). Saat ini banyak perangkat lunak basis data yang menggunakan SQL sebagai subbahasa untuk mengakses data. Beberapa diantaranya :

- $\quad D B 2$

- Ingres

- Informix

- Oracle

- Microsoft Access

- $M y S Q L$

- PostgreSQL

- $R d b$

- Sybase

Secara umum, bahasa $S Q L$ memiliki beberapa bagian yaitu :

1. Data Definition language (DDL) Menyediakan perintah untuk mendefinisikan skema relasi, menghapus relasi, serta memodifikasi skema relasi.

2. Data Manipulation Language (DML)

Mencakup bahasa SQL untuk menyisipkan rekaman pada relasi, menghapus rekaman pada relasi, serta memodifikasi rekaman pada relasi.

3. View Definition

Memuat perintah-perintah untuk mendefinisikan tampilan-tampilan (view) yang dikehendaki pengguna.

\section{Transaction Control}

Memuat perintah-perintah untuk menspesifikasikan awal dan akhir suatu bayi.

5. Embedded SQL dan Dynamic $S Q L$ Terminologi ini mencakup kemampuan SQL untuk disisipkan pada beberapa bahasa pemrograman misalnya pada Visual Basic, Delphi, $\mathrm{C}++$, Java dan sebagainya.

6. Integrity

Mencakup perintah-perintah untuk menspesifikasikan batasan-batasan integritas.

7. Authorization

Mencakup perintah-perintah untuk menspesifikasikan akses pada basis data demi alasan keamanan.

\section{Jaringan Komputer}

Jaringan komputer adalah sebuah kumpulan komputer, printer dan peralatan lainnya yang terhubung.

\section{Client-Server}

Perkembangan teknologi telah banyak membuat perubahan pada cara berpikir manusia. Dengan laju kemajuan teknologi yang semakin cepat, kebutuhan akan informasi kian hari kian meningkat sehingga menuntut kelancaran, kontinuitas dan kecepatan proses distribusi informasi. Oleh karena itu, agar kebutuhan akan informasi ini dapat dipenuhi, diperlukan sistem yang semakin canggih untuk mendistribusikan informasi yang lebih baik dan cepat.

\section{SQL SERVER}

Banyaknya peragkat aplikasi database yang beredar saat ini, maka penggunaan perangkat lunak $S Q L$ server sebagai solusi yang cukup tepat, karena selain merupakan produk terbaru dari Microsoft, perangkat lunak ini juga dilengkapi fitur-fitur tambahan yang sangat mendukung untuk penggunaan aplikasi database e-commerce. Sedangkan untuk aplikasi yang ada disini saya gunakan Visual Basic 6.0.

\section{ANALISIS DAN PERANCANGAN}

\section{Objek Yang Diteliti}

Objek yang diteliti ini adalah bagaimana pengolahan data pasien rawat inap yang terdapat pada Rumah Bersalin XAVERIUS Tanjung Karang Bandar Lampung yang dilakukan secara manual menjadi komputerisasi dalam pengolahan datanya yaitu Sistem Informasi Pelayanan Kesehatan Pasien Rawat Inap pada Rumah Bersalin XAVERIUS Tanjung Karang Bandar Lampung. 
Analisis Sistem Berjalan

Dari hasil penelitian yang dilakukan pada Rumah Bersalin XAVERIUS Tanjung Karang Bandar Lampuag diperoleh kesimpulan bahwa sistem pengolahan data pasien rawat inap masih dilakukan secara manual. Sistem manual disini maksudnya adalah segala kegiatan yang dilakukan oleh administrasi untuk pembukuan tanpa adanya komputerisasi.

\section{Uraian Masalah}

Uraian masalah dalam skripsi ini adalah bagaimana proses sistem pengolahan data pasien rawat inap oleh administrasi yang dilakukan secara manual menjadi suatu sistem yang terkomputerisasi untuk mengatasi masalah tersebut dengan tujuan menghemat waktu dan biaya.

\section{Kerangka Pemecahan Masalah}

Untuk meningkatkan kinerja dalam pengaturan pengolahan data pasien diusulkan untuk mengganti sistem manual ke dalam sistem komputerisasi yang telah dirancang dengan aplikasi bahasa pemrograman Visual Basic 6.0 dengan program database $S Q L$ Server.

\section{Diagram Konteks}

Penelitian yang dilakukan pada Rumah Bersalin XAVERIUS Tanjung Karang Bandar Lampung adalah mengenai Sistem Informasi Rawat Inap Pasien pada Rumah Bersalin XAVERIUS Tanjung Karang Bandar Lampung. Perancangan program yang akan dibuat menggunakan bahasa pemrograman Visual Basic 6.0.

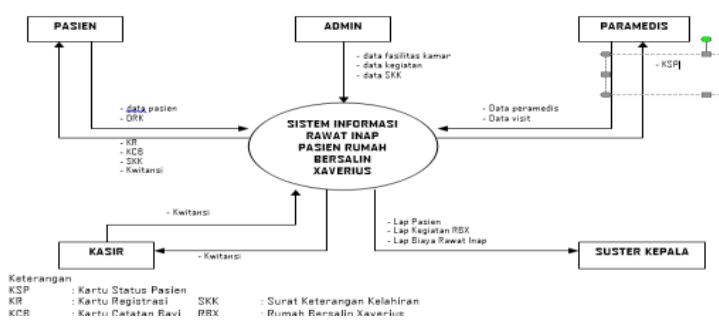

Gambar 3.6 Diagram Konteks Sistem Informasi Rawat Inap Pasien pada Rumah Bersalin XAVERIUS Tanjung Karang Bandar Lampung

\section{Desain Sistem Baru}

Desain sistem ringkas merupakan bagian dan sistem baru yang akan diusulkan dengan tujuan untuk menyelesaikan masalah secara ringkas. Dalam hal ini program penunjang yang dapat memudahkan petugas pada Rumah Bersalin XAVERIUS Tanjung Karang Bandar Lampung dalam melakukan pengolahan data pasien rawat inap adalah program Microsoft Visual Basic 6.0 dengan database SQL Server dan Crystal Report untuk membuat laporan.

\subsection{Struktur Menu Program}

Struktur menu aplikasi yang diusulkan untuk mendukung sistem adalah sebagai berikut:

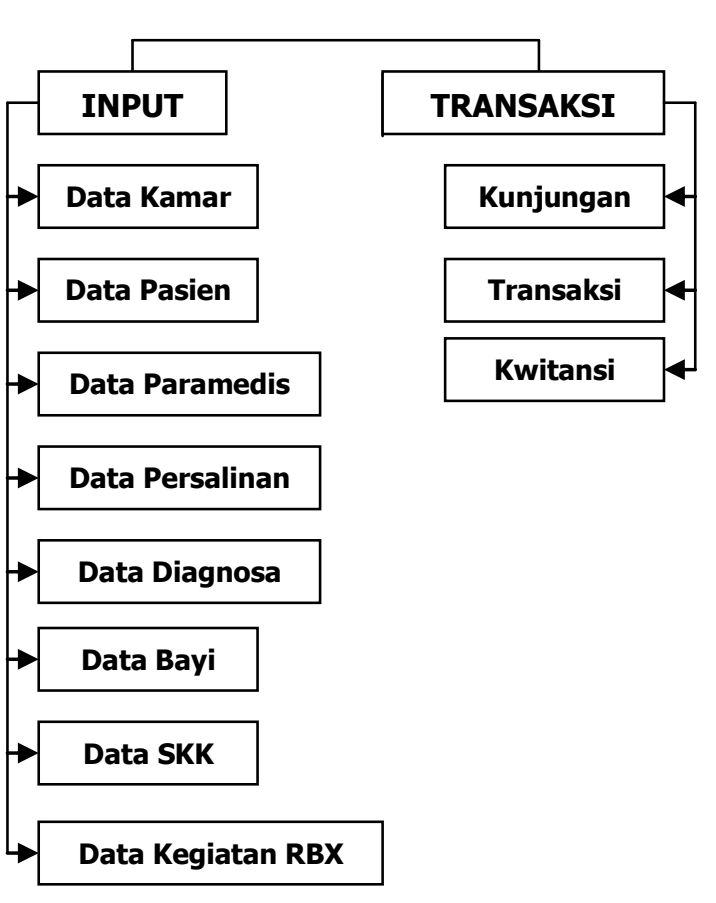

Lap BiayaRI

Lap Kegiatan RBX

Lap Pasien
Gambar 3.10 Struktur Menu Program

\section{Rancangan Masukkan (Input)}

Masukkan merupakan awal dimulainya proses informasi, oleh karena itu keakuratan data yang dimasukkan sangatlah penting. Berikut ini merupakan tampilan gambar dan tiap-tiap masukkan sesuai dengan fungsinya.

\section{Rancangan Login}

Rancangan Login dibuat untuk mengamankan sistem dan untuk kunci masuk ke sistem bagi user. Rancangan form ini terdiri dan nama user, password, tombol OK untuk masuk ke aplikasi dan tombol batal untuk membatalkan aplikasi.

\section{Rancangan Form Menu Utama}

Rancangan menu utama merupakan bagian utama pada sistem dimana user dapat memilih berbagai menu yang telah disediakan untuk kemudahan dalam menjalankan system 


\begin{tabular}{|c|c|c|}
\hline \multicolumn{3}{|c|}{ MENU UTAMA } \\
\hline FILE & LAPORAN & KELUAR \\
\hline \multicolumn{3}{|c|}{$\begin{array}{c}\text { RUMAH SAKIT BERSALIN } \\
\text { XAVERIUS } \\
\text { Jl. Mangga No } 29 \text { Tanjung Karang Telp. (0721) } 263814 \\
\text { BANDAR LAMPUNG }\end{array}$} \\
\hline
\end{tabular}

Gambar 3.12 Rancangan Form Menu Utama

\section{Rancangan Input Data Pasien}

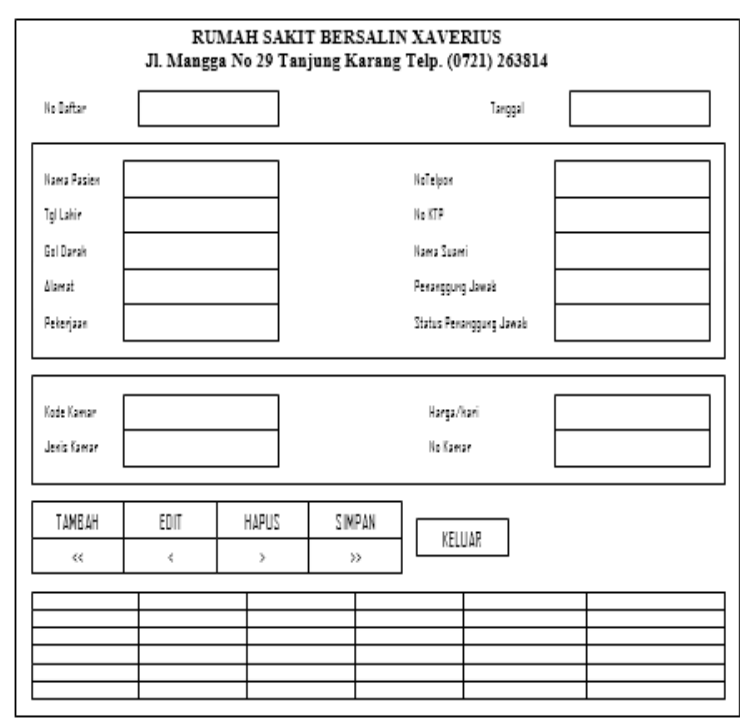

Gambar 3.13 Rancangan Input Data Pasien

\section{Rancangan Input Data Paramedis}

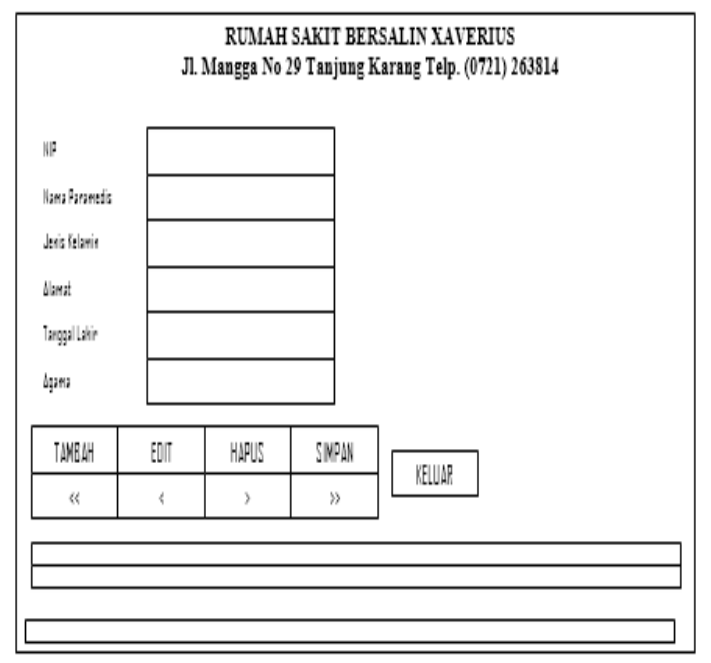

Gambar 3.14 Rancangan Input Data Paramedis

\section{Rancangan Input Data Kamar}

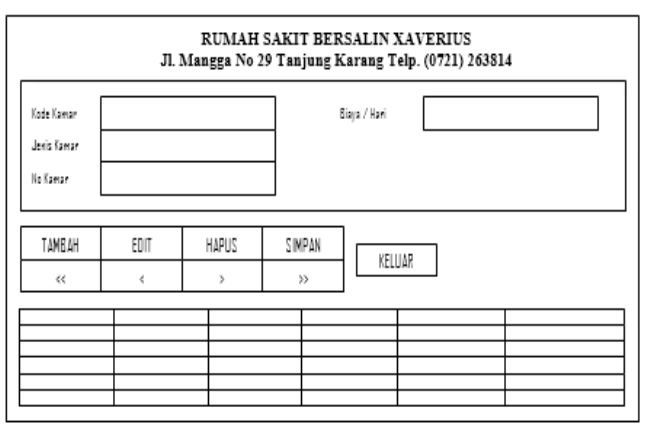

Gambar 3.15 Rancangan Input Data Kamar

\section{Flowchart Program}

Logika perancangan input dan output sistem informasi rawat map pasien pada Rumah Bersalin XAVERIUS Tanjung Karang Bandar Lampung akan lebih jelas apabila disajikan dalam bentuk flowchart program yang dapat menjelaskan setiap pengolahan data yang terjadi pada sistem. Flowchart program berikut dimulai dan input, proses pengolahan data sampai proses output dan setiap rancangan input dan output.

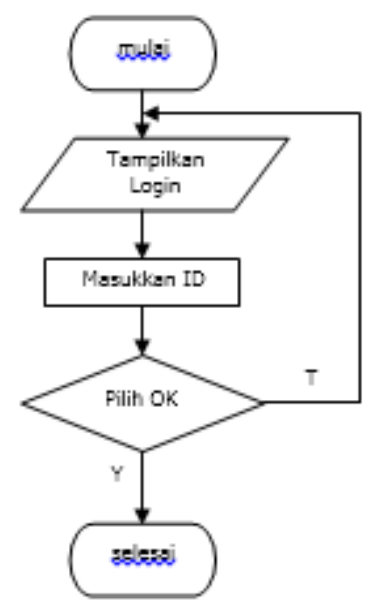

Gambar 3.35Flowchart Login

\section{IMPLEMENTASI DAN PEMBAHASAN Implementasi Sistem Baru}

Setelah melalui objek penelitian dengan mengikuti prosedur yang ada, maka hasil yang didapat dan penelitian adalah suatu program untuk Sistem Informasi Pelayanan Kesehatan Pasien Rawat Inap pada Rumah Bersalin XAVERIUS Tanjung Karang Bandar Lampung dibuat dengan aplikasi pemrograman Microsoft Visual Basic 6.0 dengan database SQL Server dan Crystal Report untuk pembuatan laporan. 


\begin{tabular}{|l|l|l|}
\hline No & Server & Client \\
\hline & Komputer Pentium & Komputer \\
1 & 4 & Pentium 4 \\
\hline 2 & Ram 1 GB & Ram 256 \\
\hline 3 & Harddisk 80 GB & Harddisk 40 GB \\
\hline & Disk Drive 3 1/2 & Disk Drive 3 1/2 \\
4 & Floopy & Floopy \\
\hline 5 & CD RAM 52x & CD RAM 52x \\
\hline 6 & Monitor 14 Inch & Monitor 14 Inch \\
\hline 7 & Keyboard & Keyboard \\
\hline 8 & Mouse & Mouse \\
\hline 9 & Printer & - \\
\hline 10 & Kartu Jaringan & - \\
\hline 11 & Kabel UTP & - \\
\hline 12 & Hub / Switch & - \\
\hline
\end{tabular}

Perangkat Pendukung Implementasi Sistem Komputerisasi

Bahan dan alat yang menulis gunakan untuk pembuatan perangka lunak, serta bahan yang menunjang lainnya. Perangkat keras yang dibutuhkan untuk pengolahan data pasien rawat inap pada Rumah Bersalin XAVERIUS Tanjung Karang Bandar Lampung, yaitu:

Perangkat Keras ( Hardware )

Untuk membuat program pengolahan data pasien rawat inap diperlukan perangkat keras yang mendukung program dapat berjalan dengan baik. Perangkat keras yang digunakan dalam sistem ini terdiri dari perangkat keras yang dipakai sebagai client dan sebagai server.

Perangkat Lunak ( Software )

Selain perangkat keras, untuk membuat program pengolahan data pasien rawat inap diperlukan juga perangkat lunak yang mendukung program aplikasi ini, perangkat lunak yang dipergunakan dalam sistem ini terdiri dan:

a. Perangkat lunak yang dibutuhkan untuk pengolahan data pasien rawat inap pada Rumah Bersalin XAVERIUS Tanjung Karang Bandar Lampung yaitu Microsoft Windows.

b. Software bahasa pemrograman yang digunakan adalah Microsoft Visual Basic 6.0 dan database menggunakan SQL Server dan Crystal Report untuk membuat laporan.

\section{Pembahasan}

\section{Menu Login}

Menu Login merupakan tampilan awal masuk dalam menu utama dengan mengisi user dan password, setelah itu OK. Bila dalam pengisian tidak sesuai, maka program tidak akan menampilkan menu utama, tombol CANCEL digunakan untuk keluar dan program. Adapun menu login dapat dilihat pada gambar sebagai berikut :

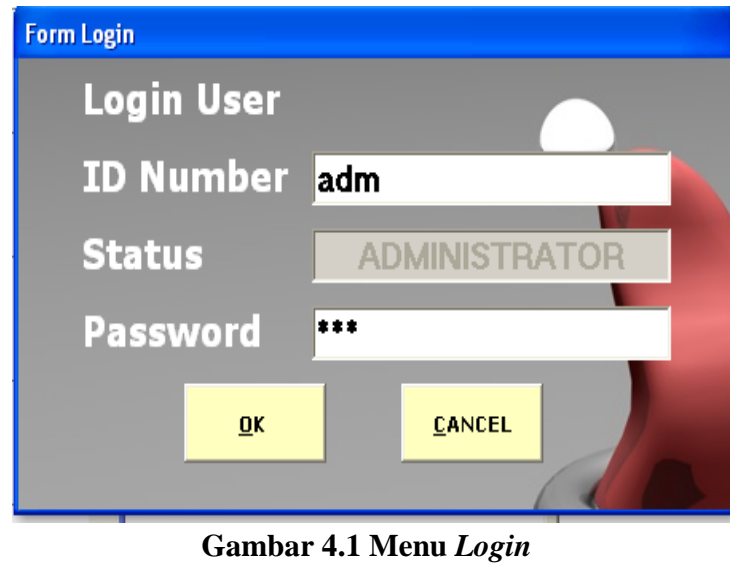

\section{Menu Utama}

Menu utama terdiri dan file, laporan, cetak dan menu keluar. Pada sub menu file terdiri dari menu input data bayi, data kamar, data pasien, data paramedis, data persalinan, data diagnosa, data SKK, kegiatan. Sedangkan pada menu transaksi terdapat menu kunjungan, transaksi, serta kwitansi. Adapun tampilan menu utama dapat dilihat pada gambar 4.2 sebagai berikut:

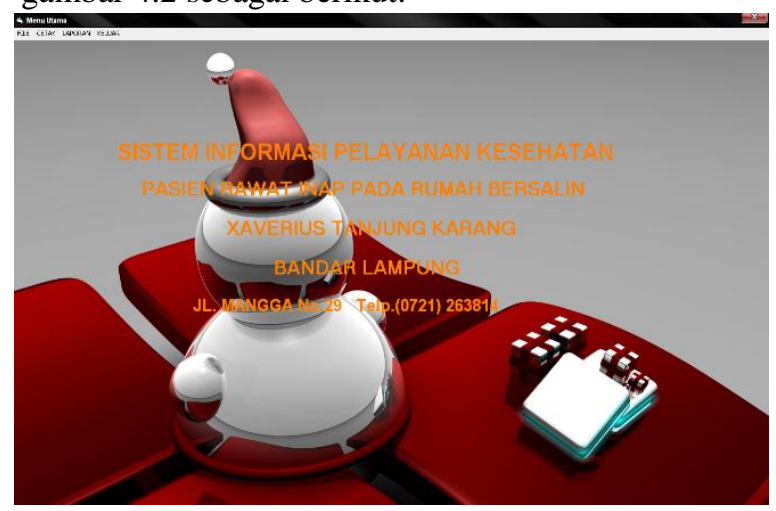

Gambar 4.2 Menu Utama

\section{Form Menu Input Data Pasien}

Form input data pasien memiliki tombol fungsi simpan yang digunakan untuk menyimpan data yang telah diinputkan, tombol fungsi tambah digunakan untuk menginput data baru, tombol fungsi hapus digunakan untuk menghapus data pasien yang telah tersimpan, tombol fungsi edit digunakan untuk mengubah data pasien dan tombol fungsi keluar digunakan untuk keluar dan form input data pasien serta kembali ke menu utama. Adapun tampilan form input data pasien dapat dilihat pada gambar 4.3 sebagai benikut: 


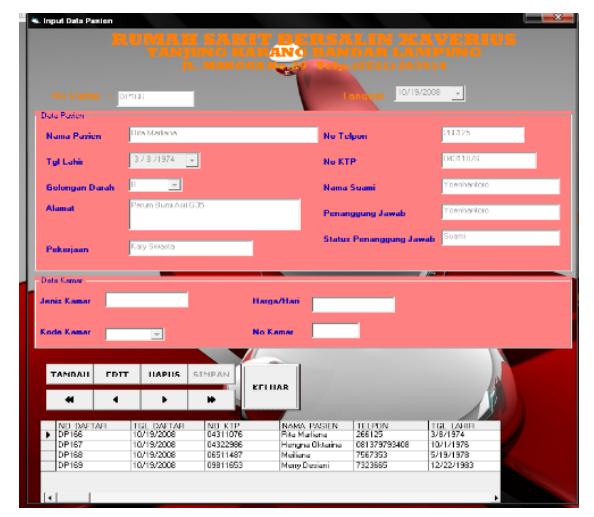

Gambar 4.3 Form Menu Input Data Pasien

\section{Form Input Data Kamar}

Form input data kamar terdiri dan kode kamar, jenis kamar, no kamar, dan biaya kamar perhari. Terdiri dan beberapa tombol yaitu tombol fimgsi simpan digunakan untuk menyimpan data yang telah diinputkan, tombol fungsi tambah digunakan untuk menambah data kamar, tombol fungsi edit digunakan untuk mengubah data yang telah diinputkan, tombol fungsi hapus digunakan untuk menghapus data pasien yang telah tersimpan, sedangkan tombol fungsi keluar digunakan untuk keluar dan menu form input data kamar serta kembali ke menu utama. Adapun tampilan form input data kamar dapat dilihat pada gambar 4.4 sebagai berikut:

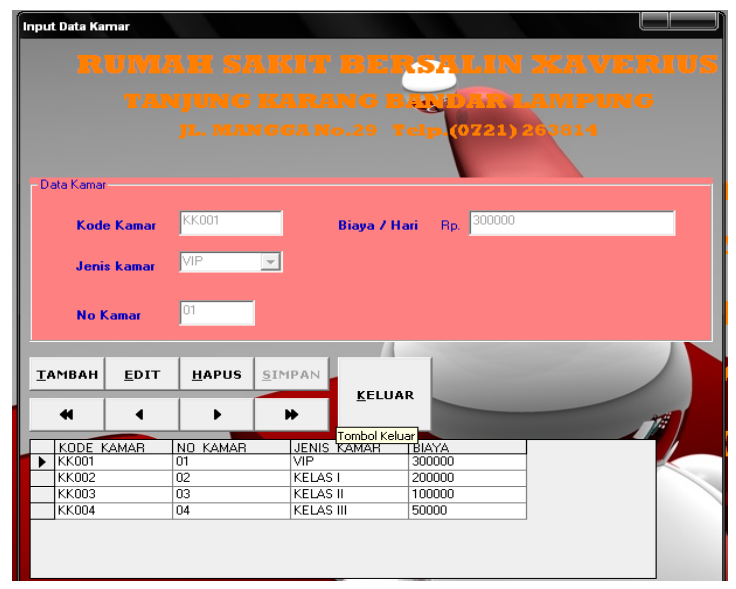

\section{Gambar 4.4 Form Input Data Kamar}

\section{Form Input Data Paramedis}

Forminput data paramedis terdiri dan NIP, nama paramedis, jenis kelamin, alamat, tanggal lahir, dan agama. Terdiri dan tombol fungsi simpan, tambah, edit, hapus dan keluar. Tombol fungsi simpan digunakan untuk menyimpan data paramedis yang telah diinputkan. Tombol fungsi tambah digunakan untuk menambah data paramedis, tombol fungsi edit digunakan untuk mengubah data paramedis yang telah diinputkan, tombol fungsi hapus digunakan untuk menghapus data paramedis yang telah tersimpan, sedangkan tombol fungsi keluar digunakan untuk keluar dan menu form input data paramedis serta kembali ke menu utama. Adapun tampilan form input data paramedis dapat dilihat pada gambar 4.5 sebagai berikut:

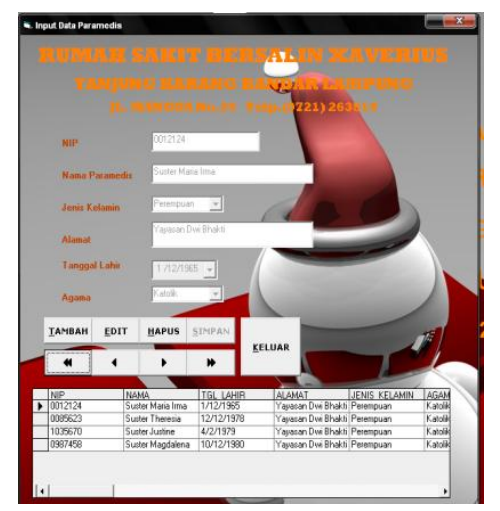

Gambar 4.5 Form Input

\section{Form Input Data Diagnosa}

Form input data diagnosa terdiri dan data-data pasien, keadaan kehamilan sekarang dan yang lalu, keadaan puerperium yang lalu, jumlah anak yang hidup. Sedangkan pada data diagnosa terdini dan Menarche, Cyclus, Dysmenorhoe, Flour Albus, Mictie, Defaecatie, penyakit yang pernah didenita serta alergi pasien terhadap sesuatu. Tombol fungsi simpan digunakan untuk menyimpan data diagnosa yang telah diinputkan.

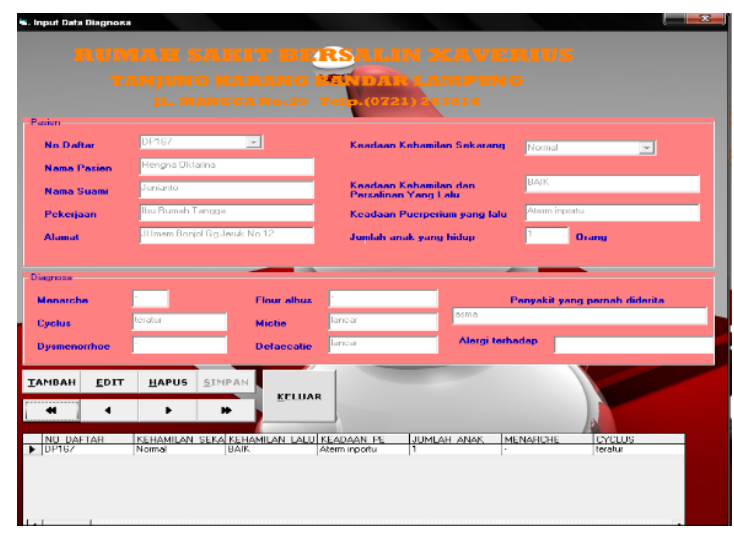

Gambar 4.6

\section{Form Input Data Persalinan}

Form input data persalinan terdiri dan data-data pasien, tanggal kelahiran bayi, jam lahir, jenis kelamin, nama anak, berat dan panjang bayi. Tombol fungsi simpan digunakan untuk menyimpan data persalinan yang telah diinputkan. 


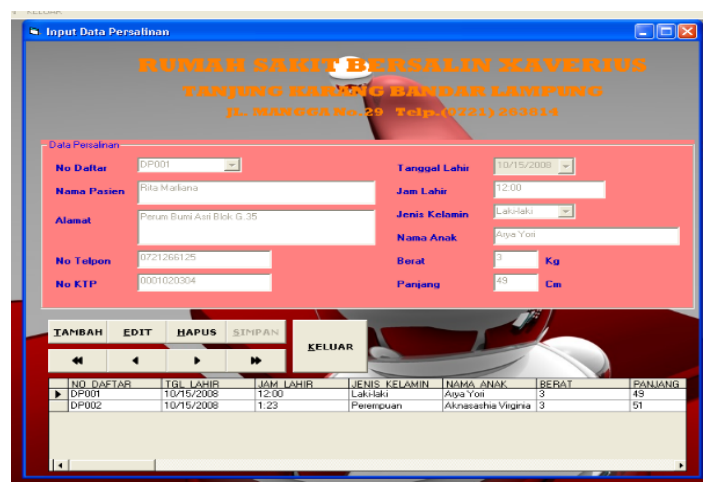

Gambar 4.10 Form Input

\section{Form Input Data Kunjungan Visit}

Form input data kunjungan visit terdiri dan data-data pasien serta data - data visit, yaitu no visit, tanggal visit, biaya visit, defikasi, urine, berat bayi, tanggal masuk dan tanggal keluar. Tombol fungsi simpan digunakan untuk menyimpan data visit yang telah diinputkan.

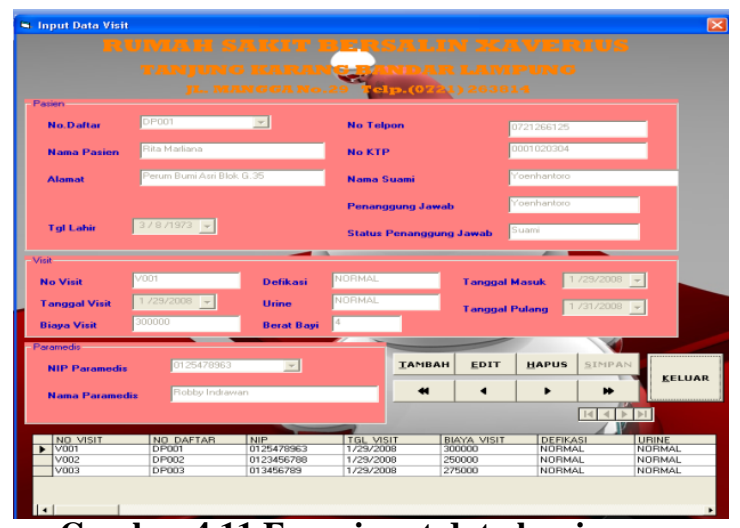

Gambar 4.11 Form input data kunjungan

\section{SIMPULAN DAN SARAN}

\section{Simpulan}

Berdasarkan analisis pembahasan hasil penelitian tentang pengolahan data rawat inap pada Rumah Bersalin XAVERIUS Tanjung Karang Bandár Lampung, maka dapat diambil kesimpulan sebagai berikut:

1. Dalam mengolah informasi yang dibutuhkan masih kurang efisien karena pendataan masih dilakukan secara manual, sehingga memakan waktu dalam pencarian data.

2. Perancangan sistem komputerisasi dibuat agar memudahkan dalam pengolahan data pasien rawat inap, sehingga dalam menyajikan informasi menjadi lebih mudah dengan rnenggunakan bahasa pemrograman Microsoft Visual Basic 6.0 dengan database SQL Server dan Crystal Report untuk pembuatan laporan.

\section{Kesimpulan Sistem Baru}

Berdasarkan penulisan laporan skripsi serta analisis pembahasan dari hasil penelitian mengenai pengolahan data rawat inap pada Rumab Bersalin XAVERIUS Tanjung Karang Bandar Lampung dapat ditarik kesimpulan bahwa:

1. Dari prosedur sistem lama dimana masih dilakukan secara manual, sekarang sudah terkamputerisasi sehingga waktu yang dibutuhkan dalam proses pengolahan datanya dapat efektif dan efisien.

2. Pencatatan serta penyimpanan sudah menggunakan database tidak lagi menggunakan buku besar.

3. Dalam sistem baru ini terdapat form surat keterangan kelabiran yang nantinya akan digunakan sebagai data bukti kelahiran.

Saran

Berdasarkan pengalaman dan pengetahuan yang penulis dapatkan selama melakukan penelitian pada Rumah Bersalin XAVERIUS Tanjung Karang Bandar Lampung, penulis dapat memberi saran sebagai berikut :

1. Sistem pengolahan data pasien rawat inap sebaiknya menggunakan program aplikasi Microsoft Visual Basic 6.0 dengan database SQL Server dan Crystal Report untuk leblh memperlancar proses dalam mengolah data maupun dalam pembuatan laporan.

2. Penggunaan sistem komputerisasi hams dioptimalkan sehingga dapat memberikan kemudahan untuk menghasilkan data-data yang diperlukan secara cepat dan efisien.

\section{DAFTAR PUSTAKA}

1. Budiharto, Widodo. 2004. Aplikasi Database dengan SQL Server \& Visual Basic 6. Jakarta. Elex Media Komputindo.

2. Hartono, Jogiyanto. 2001. Analisis \& Desain Sistem Informasi Pendekatan Tersrtuktur dan Praktek Aplikasi. Jakarta.Andi Offset.

3. Hartono, Jogiyanto. 2002. Pengenalan Komputer: dasar Ilmu Komputer, Pemrograman, Sistem Informasi dan Intelegensi Buatan. Yogyakarta : Edisi ketiga. Andi Offset.

4. Kurniadi, Adi. 2001. Pemrograman Microsoft Visual Basic 6.0. Jakarta. Elexmedia Komputindo.

5. Kadir, Abdul. 2003. Penuntun Praktis Belajar $S Q L$. Yogyakarta. Andi Offset.

6. Tim penyusun Buku Panduan. 2007. Panduan Penulisan Laporan PKL, Proposal Tugas Akhir dan Tugas akhir. Bandar Lampung. Perguruan Tinggi TEKNOKRAT. 